\title{
BEZPOŚREDNIE STOSOWANIE KONSTYTUCJI W ORZECZNICTWIE SĄDOWYM ${ }^{1}$
}

\section{UWAGI OGÓLNE}

Bezpośrednie stosowanie Konstytucji nie jest w polskim systemie prawnym niczym nowym. Choć dominujący dotychczas paradygmat wykładniczy w znacznym stopniu limitował aktywność sądów w obszarze bezpośredniego stosowania Konstytucji, sprzeciwiając się stosowaniu reguł walidacyjnych, a do stosowania wykładni prokonstytucyjnej podchodząc bardzo ostrożnie, to jednak analiza orzeczeń sądowych pozwala dostrzec wiele przykładów opierania - z różnym natężeniem i w różnych formułach - podstawy orzeczenia na normach konstytucyjnych. Zwykle normy konstytucyjne nie stanowia samodzielnej podstawy rozstrzygnięcia sądowego, lecz ich wpływ na kształt rozstrzygnięcia jest dostrzegalny w orzecznictwie w formule interpretacji prokonstytucyjnej, interpretacji w zgodzie z Konstytucja, czy też w formie współstosowania. Bywaja też one widoczne jako czynnik bezpośrednio kształtujący treść orzeczenia sądowego, czy to jako samodzielna podstawa rozstrzygnięcia, czy też jako podstawowy czynnik eliminujący niższe hierarchicznie elementy systemu normatywnego $\mathrm{w}$ formule stosowania reguły kolizyjnej lex superior z wszelkimi jej implikacjami w fazie aplikacyjnej.

Wspólne dla omawianych judykatów jest wskazanie Sądu Najwyższego, że praktyka sądowa musi uwzględniać „postanowienia ustawy rangi zasadniczej, hierarchiczne usytuowanie której - w obowiązującym porządku prawnym i nakaz bezpośredniego stosowania przepisów (Konstytucji art. 8) - nie moga być pomijane przy wykładni i stosowaniu ustaw zwykłych majacych zapewnić realizację konstytucyjnej powinności sądów rozpatrzenia każdej sprawy bez nieuzasadnionej zwłoki (art. 45 ust. 1 Konstytucji). Ranga zaś i znaczenie tego postanowienia została zrównana w powołanym przepisie Konstytucji z podstawowymi zasadami funkcjonowania sądów (niezależność, bezstronność i niezawisłośćc)"2. Trafność tego stwierdzenia nie może być kwestionowana.

Możliwą krótkoterminowa rozbieżność orzeczniczą pomiędzy orzeczeniami poszczególnych sądów w dłuższej perspektywie łagodzi i koryguje fakt, że

${ }^{1}$ Artykuł opiera się na referacie wygłoszonym na konferencji, przedstawiającym koncepcję zaprezentowana w monografii M. Gutowskiego i P. Kardasa, Wyktadnia i stosowanie prawa w procesie opartym na Konstytucji, Warszawa 2017. W szczególności przedmiotem artykułu uczyniono część orzeczeń obszernie omówionych w rozdz. 7 tej monografii.

${ }^{2}$ Wyr. SN z 24 stycznia 2001 r., II CKN 28/01, niepubl. 
ostateczną kontrolę prawidłowości bezpośredniego stosowania Konstytucji sprawują Sąd Najwyższy i Naczelny Sąd Administracyjny, co obrazuje cytat z jednego z orzeczeń SN: „Stosownie do zasad ustrojowych normujacych porządek władzy sądowniczej, kształtowanych przez Konstytucję i ustawy dotyczące procedur sądowych podstawową funkcją jurysdykcyjną Sądu Najwyższego jest nadzór nad działalnością sądów przez zapewnienie zgodności z prawem i jednolitości orzeczeń sądów powszechnych i sądów wojskowych. W postępowaniu cywilnym nadzór ten polega przede wszystkim na dokonywaniu oceny prawidłowości wykładni i stosowania prawa przez sądy powszechne, natomiast ustalenia faktyczne stanowiące podłoże rozpoznawanych spraw oraz poprzedzajaca je ocena dowodów pozostaje domeną sądów meriti" ". Istniejący w polskim systemie prawnym mechanizm kontroli instancyjnej orzeczeń pozwala na przestrzeni pewnego czasu zniwelować różnice na poziomie wykładniczym i aplikacyjnym. Jednocześnie czyni to przy wykorzystaniu pełnej wiedzy płynącej z rozpoznawanych spraw, na podstawie realnie występujących problemów w praktyce i przy wykorzystaniu siły orzeczniczej wszystkich sądów w Polsce.

\section{OCENA ZARZUTÓW NARUSZENIA NORM KONSTYTUCYJNYCH}

Typowego i powszechnego przykładu bezpośredniego stosowania Konstytucji dostarcza wiele orzeczeń sądowych, które odwołują się do norm konstytucyjnych jako do podstawy oceny wyraźnie sformułowanych zarzutów lub podstaw wskazanych w środkach odwoławczych ${ }^{4}$. Sądy wszakże oceniają w toku postępowania wskazane przez pełnomocników lub obrońców twierdzenia, wnioski i zarzuty odnoszące się do przepisów zawierających normy określające prawa i obowiązki konstytucyjne i na tej podstawie podejmuja decyzje dowodowe, wykładnicze i aplikacyjne. Sformułowane przez stronę żądanie obliguje sąd do dokonania analizy konsekwencji konstytucyjnych na gruncie obowiąku bezpośredniego stosowania Konstytucji przez sąd (art. 8 ust. 2).

\footnotetext{
${ }^{3}$ Post. SN z 23 września 2010 r., III CSK 288/08, Legalis.

${ }^{4}$ Por. np. post. SN z 31 stycznia 2017 r., I CSK 523/15, Legalis; wyr. SN z 18 listopada 2016 r., I CSK 823/15, Legalis; wyr. SN z 7 kwietnia 2016 r., II CSK 522/15, Legalis; wyr. SN z 2 marca 2016 r., V CSK 399/15, Legalis; wyr. SN z 2 października 2015 r., II CSK 662/14, Legalis; wyr. SN z 6 marca 2015 r., V KK 376/14, Legalis; post. SN z 12 marca 2014 r., II PK 268/13, Legalis; wyr. SN z 10 listopada 2010 r., III KRS 14/10, Legalis; wyr. SN z 8 stycznia 2009 r., I CSK 482/08, Legalis; post. SN z 3 grudnia 2007 r., III KK 338/07, Legalis; post. SN z 10 lutego 2004 r., IV CZ 8/04, Legalis; post. SN z 2 kwietnia 2004 r., I PZ 3/04, Legalis; post. NSA z 18 stycznia 2017 r., II OZ 9/17, Legalis; post. NSA z 5 stycznia 2017 r., I FSK 572/15, Legalis; wyr. WSA w Gorzowie Wlkp. z 7 grudnia 2016 r., II SA/Go 874/16, niepubl.; wyr. WSA w Poznaniu z 1 grudnia 2016 r., III SA/Po 636/16, niepubl.; wyr. NSA z 25 listopada 2016 r., I OSK 3139/14, Legalis; post. NSA z 24 listopada 2016 r., I FSK 1361/16, Legalis; wyr. WSA w Łodzi z 10 listopada 2016 r., III SA/Łd 804/16, niepubl.; wyr. NSA z 4 listopada 2016 r., II FSK 1047/14, Legalis; wyr. SN z 10 kwietnia 2013 r., IV CSK 542/12, Legalis; wyr. SN z 24 października 2013 r., IV CSK 39/13, Legalis; wyr. SN z 15 maja 2014 r., II CSK 444/13, Legalis.
} 
Umiejętne wykorzystywanie zarzutów opartych na gwarancjach konstytucyjnych jest środkiem do osiagania realnych celów procesowych w postaci oczekiwanych przez stronę i korzystnych dla niej rozstrzygnięć. Już choćby z tego powodu bezpośrednio stosowana Konstytucja w indywidualnych sprawach sądowych stanowi element instrumentarium prawniczego, którego znaczenie nie może być deprecjonowane ani lekceważone.

\section{PROKONSTYTUCYJNA WYKŁADNIA I WYKLADNIA W ZGODZIE Z KONSTYTUCJĄ}

Ważnym sposobem bezpośredniego stosowania Konstytucji w indywidualnych sprawach sądowych jest prokonstytucyjna wykładnia lub znaczeniowo niemal tożsama - wykładnia w zgodzie z Konstytucją. Stanowi ona operację myślową wymagającą orzeczniczego rozumowania, w którym sądy podejmą próbę ukierunkowanej interpretacji ustawy i Konstytucji pod kątem ustalonego uprzednio stanu faktycznego w celu współuzgodnienia, a następnie współaplikacji normy konstytucyjnej i ustawowej. Wykładnia w zgodzie z Konstytucją jest w istocie jej nieco mniej złożoną formuła. Jeden z przykładów prokonstytucyjnej wykładni stanowić może judykat ${ }^{5}$, w którym wskazano, że o „niespełnieniu warunków, o których mowa w art. 89 ust. 5-15 ustawy o podatku akcyzowym”, nie przesądza jedynie nieterminowe złożenie zestawień oświadczeń nabywców paliwa opałowego. Do zastosowania stawki dla paliw silnikowych wymagane jest bowiem ustalenie, że transakcja kupna-sprzedaży zrealizowana została niezgodnie z prawnopodatkowym przeznaczeniem oferowanego na sprzedaż wyrobu akcyzowego, by regulacja zgodna była z art. 217 Konstytucji.

Dekodowanie normy z przepisów ustawowych i konstytucyjnych za pomocą odpowiednich narzędzi wykładniczych również jest w praktyce rozumowaniem typowym. Norma konstytucyjna zwykle wykorzystana zostaje przez sąd jako mechanizm korygujaccy - wzorzec kontroli normy ustawowej, wyznaczając dopuszczalny na gruncie zasad konstytucyjnych sposób interpretacji. Przykładowo w wyroku NSA z 2016 r. ${ }^{6}$ zakwestionowano stanowisko organu i WSA, w myśl którego decyzja wojewody udzielająca ojcu skarżacej zezwolenia na osiedlenie się na terytorium Rzeczypospolitej Polskiej nie stanowi dowodu na posiadanie narodowości polskiej przez jej adresata. NSA podkreślił, że art. 52 ust. 2 Konstytucji stanowi, że osoba, której pochodzenie polskie zostało stwierdzone zgodnie z ustawą, może osiedlić się na terytorium Rzeczypospolitej Polskiej na stałe, a zatem przesłanką do wydania zezwolenia na osiedlenie się jest stwierdzenie posiadania polskiego pochodzenia. Skoro więc zezwolono na osiedlenie się, to oznacza, że ustalenie posiadania polskiego pochodzenia wiąże organ administracji na mocy art. 110 k.p.a.

\footnotetext{
5 Wyr. WSA w Poznaniu z 6 grudnia 2016 r., III SA/Po 650/16, Legalis.

${ }^{6}$ Wyr. NSA z 30 listopada 2016 r., II OSK 546/15, Legalis.
} 
Orzecznictwo dostarcza wielu przykładów prokonstytucyjnej wykładni na gruncie: własności ${ }^{7}$, relacji konstytucyjnych gwarancji własności do instytucji nadużycia prawa przez właściciela ${ }^{8}$, zasiedzenia jako instytucji ograniczajacej konstytucyjna zasadę nienaruszalności prawa własności ${ }^{9}$, wpływu zasady ochrony wierzycieli na konstytucyjną ochronę własności ${ }^{10}$, relacji pomiędzy rękojmia wiary publicznej ksiag wieczystych a konstytucyjna ochrona prawa własności ${ }^{11}$, relacji wspólnota - właściciele lokali ${ }^{12}$, swobody działalności gospodarczej ${ }^{13}$, rozwiazania stosunku pracy ${ }^{14}$, zakazu wywodzenia retroaktywnego działania ustawy z jej celu ${ }^{15}$, zasad zaliczania przedmiotów majątkowych w czasie trwania ustawowej wspólności majątkowej małżeńskiej ${ }^{16}$, instytucji refundacji wyrównującej aptekom różnicę pomiędzy cenami rynkową leku a jego ceną detaliczną dla ubezpieczonego konsumenta na tle art. 68 Konstytucji ${ }^{17}$, relacji majątkowych pomiędzy spółdzielnią a jej członkami ${ }^{18}$, relacji pomiędzy ochroną własności a ochroną lokatorów ${ }^{19}$, relacji pomiędzy prawem własności a możliwością ustanowienia służebności przesyłu ${ }^{20}, \mathrm{w}$ tym na tle roszczeń negatoryjnych o usunięcie urządzeń przesyłowych ${ }^{21}$, charakteru prawnego odrębnej własności lokalu ${ }^{22}$, konstytucyjnej zasady równej dla współwłaścicieli ochrony prawnej własności i innych praw majątkowych na podstawie art. 64 ust. 2 Konstytucji ${ }^{23}$ albo zarządzenia wykonania kary pozbawienia orzeczonej z warunkowym jej zawieszeniem ${ }^{24}$. Prokonstytucyjna wykładnia wymaga często złożonego rozumowania uwzględniającego ważenie wartości leżących u podstaw poszczególnych przepisów w rozmaitych aktach normatywnych. Przykładowo rozpatrywanie zarzutów naruszenia zasady konstytucyjnej ochrony prawa własności wymaga obiektywnej oceny sądu

7 Wyr. SN z 24 czerwca 2009 r., I CSK 534/08, niepubl.

8 Post. SN z 2 czerwca 2011 r., I CSK 520/10, Legalis; wyr. SN z 26 stycznia 2011 r., II CSK 335/10, Legalis.

9 Post. SN z 23 września 2009 r., I CSK 99/09, Legalis; post. SN z 24 października 2002 r., I CKN 1006/00, Legalis; post. SO w Koninie z 27 stycznia 2017 r., II Ca 482/16; post. SR Poznań Grunwald-Jeżyce z 13 listopada 2015 r., I Ns 2165/14, niepubl.; wyr. SR Poznań Grunwald-Jeżyce z 16 lutego 2016 r., I C 1369/14, niepubl.

10 Wyr. SN z 16 lutego 2011 r., II CSK 406/10, Legalis.

11 Uchw. SN (7) z 15 lutego 2011 r., III CZP 90/10, Legalis.

12 Wyr. SN z 3 kwietnia 2009 r., II CSK 600/08, Legalis.

${ }^{13}$ Post. SR w Gliwicach z 26 stycznia 2017 r., IX K 1467/16, niepubl.

${ }^{14}$ Wyr. SO w Częstochowie z 21 października 2011 r., IV P 24/10, niepubl.; wyr. SO w Częstochowie z 26 grudnia 2013 r., IV P 35/12, niepubl.

15 Wyr. SN z 26 stycznia 2006 r., II CK 374/05, Legalis; post. SN z 16 grudnia 2003 r., II CK 328/02, Legalis.

${ }_{16}$ Post. SN z 28 czerwca 2002 r., I CKN 884/00, Legalis.

17 Post. SN z 11 stycznia 2007 r., V CSK 388/06, Legalis.

18 Wyr. SN z 11 stycznia 2006 r., II CSK 30/05, Legalis.

19 Wyr. SN z 5 marca 2002 r., I CKN 737/00, Legalis; wyr. SR Poznań-Grunwald i Jeżyce z 25 czerwca 2015 r., I C 1725/14.

${ }^{20}$ Wyr. SO w Koninie z 3 czerwca 2015 r., II Ca 115/16, niepubl.

21 Wyr. SO w Zielonej Górze z 29 listopada 2016 r., I C 181/16.

22 Por. wyr. SN z 7 stycznia 2004 r., III CK 186/02, Legalis.

${ }^{23}$ Post. SN z 12 kwietnia 2001 r., II CKN 658/00, Legalis.

${ }_{24}$ Post. SA w Szczecinie z 4 marca 2015 r., II AKa 116/14; post. SA w Szczecinie z 26 stycznia 2017 r., II AKz 24/17. 
z punktu widzenia treści i granic tego prawa oraz jego wykonywania (art. 140 k.c.), z uwzględnieniem interesów właściciela i innych podmiotów ${ }^{25}$. W ramach prokonstytucyjnej wykładni przepisów normujących uprawnienia ZUS do weryfikacji podstawy składki na ubezpieczenie społeczne wskazano, że bez naruszenia zasady równości nie sposób wywieść kompetencji ZUS do weryfikacji podstawy wymiaru składki płatników prowadzących działalność gospodarczą w sytuacji, gdy ZUS pobierał składkę na podstawie umowy w tamtym czasie niekwestionowanej ${ }^{26}$.

\section{WSPÓŁSTOSOWANIE KONSTYTUCJI I USTAW}

Współstosowanie Konstytucji i ustaw to w istocie stosowanie normy rozczłonkowanej syntaktycznie lub treściowo w przepisach rangi konstytucyjnej i ustawowej. W istocie i konstrukcji swej nie różni się ono w sposób znaczący od wykładni prokonstytucyjnej. Różnica polega w zasadzie na stopniu wykorzystania w procesie dekodowania stosowalnej normy przepisów konstytucyjnych. Przy współstosowaniu zakres rekonstrukcji normy na podstawie konstytucji jest szerszy niż w przypadku prokonstytucyjnej wykładni lub wykładni w zgodzie z konstytucją. Mówiąc o współstosowaniu ustaw i Konstytucji, warto mieć na uwadze stanowisko SN z 2000 r. ${ }^{27}$, akcentujące konieczność oceny relacji pomiędzy współaplikowanymi przepisami w realiach konkretnej sprawy: „Hierarchiczne usytuowanie Konstytucji (art. 8 ust. 1) i obowiązek bezpośredniego stosowania jej przepisów (art. 8 ust. 2) nie powinien pozostawać bez wpływu na stosowanie przez sądy przepisów kodeksu postępowania cywilnego mających zapewnić realizację zasady konstytucyjnej rozpoznania sprawy bez nieuzasadnionej zwłoki (art. 45 ust. 1 Konstytucji)”. W istocie, mówiąc o współstosowaniu Konstytucji i ustaw, mamy na myśli proces wykładniczy zmierzający do zdekodowania normy, której pełna rekonstrukcja wymaga odwołania się do przepisów aktów normatywnych różnej rangi w celu wydobycia z nich poszczególnych składników tej normy w sposób spójny i zgodny, zwłaszcza z systemowymi dyrektywami wykładni (choć nie tylko). Taki mechanizm wykładniczo-aplikacyjny bardzo często występuje w orzecznictwie sądowym. Mechanizm ten jest nie tylko dopuszczalny, lecz w wielu sprawach wręcz konieczny. Moc wiążąca wyroków TK jest wąska, ograniczona w istocie do derogacji przepisu uznanego za niezgodny z Konstytucja. Tym samym w indywidualnych postępowaniach sądowych pojawia się konieczność skonkretyzowania ogólnej reguły dla potrzeb relewantnej sytuacji prawnej.

Przykładem współstosowania przepisów Konstytucji i Prawa o ustroju sądów powszechnych (p.u.s.p.) na gruncie ustrojowej pozycji sędziego - wywodzonej m.in. z art. 45 ust. 1 Konstytucji - jest przesądzenie, że uprawnienie do delegowa-

25 Wyr. SN z 7 sierpnia 2014 r., II CSK 775/13, Legalis.

${ }^{26}$ Wyr. SO w Częstochowie z 12 grudnia 2014 r., IV U 1367/14, niepubl.; wyr. SO w Częstochowie z 18 lutego 2015 r., IV U 1787/14, niepubl.

27 Wyr. SN z 28 czerwca 2000 r., IV CKN 77/00, Legalis. 
nia sędziego do pełnienia obowiązków sędziego w innym sądzie przysługuje wyłącznie Ministrowi Sprawiedliwości i nie może być przenoszone na inne osoby. SN podkreślił, że zgodnie z jedną z fundamentalnych zasad ustroju sądów, mająca także wymiar konstytucyjny (art. 45 ust. 1 Konstytucji), sędzia może i powinien wykonywać władzę tylko w tym w sądzie, w którym ma swoje miejsce służbowe (art. 55 ust. $3 \mathrm{w}$ zw. z art. 77 p.u.s.p. i art. 180 ust. 2 Konstytucji) ${ }^{28}$.

Współstosowanie przepisów Konstytucji i przepisów aktów prawnych hierarchicznie niższych może przybierać różne postacie. Najprostszajest ocena, czy akt normatywny należy do wskazanych w art. 87 Konstytucji źródeł prawa powszechnie obowiąującego ${ }^{29}$. Na przykład SN przesądził, że przepisy prawa kanonicznego nie sa przepisami prawa powszechnie obowiązującego w Rzeczypospolitej Polskiej w świetle zasady poszanowania autonomii wyrażonej w art. 25 ust. 3 Konstytucji i w art. 1 Konkordatu, a także wskazanego w art. 87 Konstytucji katalogu źródeł prawa ${ }^{30}$. W innym orzeczeniu przesądzono, że nieogłoszona uchwała w dzienniku urzędowym nie jest aktem prawa miejscowego w rozumieniu art. 87 ust. 2 Konstytucji ${ }^{31}$.

Ciekawe przypadki współstosowania Konstytucji w ramach kreowanego przez strony na podstawie art. $353^{1}$ k.c. stosunku prawnego widoczne sa na tle analizy obowiązku świadczeń „ponadlimitowych” opłat za zabiegi ratujące życie. SN stwierdził, że w omawianym zakresie kasy chorych finansuja realizację obowiązku państwa w zakresie zapewnienia obywatelom nieodpłatnego dostępu do świadczeń opieki zdrowotnej (art. 68 Konstytucji RP), a zatem w zakresie obligatoryjnych zabiegów obowiązek zapłaty - nawet ponadkwotowe limity przewidziane w umowie - stanowi czynnik kształtujący treść stosunku z mocy ustawy (art. 56 k.c.). Skoro przedmiotem umów było wykonanie usług, a pozwana nie wywiązała się z ciążącego na niej obowiązku zapłaty za wykonane przez powoda usługi „ponadlimitowe”, uzasadnione było zasądzenie dochodzonej kwoty zgodnie z współstosowanymi przepisami oraz art. 471 k.c. ${ }^{32}$ Współstosowanie Konstytucji i k.c. pozwoliło też na ocenę wadliwej precyzacji okresu posiadania wymaganego do zasiedzenia nieruchomości ${ }^{33}$.

Szczególnie ważny w świetle problematyki współstosowania ustaw i Konstytucji jest art. 31 ust. 3 określający zasadę proporcjonalności. Przepis ten ma znaczenie nie tylko $\mathrm{w}$ orzecznictwie $\mathrm{TK}^{34}$, lecz przede wszystkim w orzecz-

${ }^{28}$ Uchw. SN z 17 lipca 2007 r., III CZP 81/07, Legalis.

${ }^{29}$ Por. np. wyr. SN z 18 grudnia 2003 r., I CK 10/03, Legalis.

${ }^{30}$ Uchw. SN z 19 grudnia 2008 r., III CZP 122/08, Legalis.

${ }^{31}$ Wyr. SN z 25 maja 2011 r., II CSK 570/10, Legalis.

${ }^{32}$ Wyr. SN z 22 grudnia 2004 r., III CK 17/04, Legalis; wyr. SN z 8 sierpnia 2007 r., I CSK 125/07, Legalis; wyr. SN z 12 marca 2009 r., V CSK 272/08, Legalis.

${ }^{33}$ Post. SN z 10 kwietnia 2008 r., IV CSK 21/08, Legalis.

${ }^{34}$ Przykładem orzeczenia o niekonstytucyjności regulacji prawnej ze względu na naruszenie zasady proporcjonalności w zakresie kary jest wyrok TK z 1 lipca 2014 r., SK 6/12, OTK-A 2014, $\mathrm{nr} 7$, poz. 68 , w sprawie usunięcia drzew bez wymaganego zezwolenia. Trybunał wskazał, że państwo może nakładać administracyjne kary pieniężne za naruszenia prawa spoza systemu prawa karnego, ale swoboda ustawodawcy nie jest tu nieograniczona, a kary muszą być przede wszystkim proporcjonalne do rangi naruszenia. W ocenie Trybunału zasady wymierzania kar pieniężnych za wycinkę drzew lub krzewów bez zezwolenia z własnej działki są niekonstytucyjne w zakresie, w jakim nie przewidują zmniejszania kar w szczególnych sytuacjach, nadto nie 
nictwie sądowym, w płaszczyźnie bezpośredniego stosowania ustawy zasadniczej. Jak wskazuje SN, sąd powszechny ma kompetencje do zbadania proporcjonalności interwencji funkcjonariuszy na lotniskach dokonujaccych kontroli osobistej skarżącego również, jeśli funkcjonariusze Straży Granicznej działali na podstawie obowiąujących przepisów prawnych. Samo istnienie ustawowego upoważnienia do kontroli manualnej nie wystarcza - jak podkreśla SN - do uchylenia bezprawności, gdyż sama kontrola w konkretnej sprawie podlegać musi ocenie w zakresie proporcjonalności zastosowanych środków. Prawo do rzetelnego procesu, wyrażone w art. 45 ust. 1 Konstytucji RP oraz w art. 6 ust. 1 Konwencji o ochronie praw człowieka i podstawowych wolności (EKPC), oznacza bowiem, że z uwagi na art. 77 ust. 2 i art. 177 Konstytucji RP istnieje wręcz konieczność przeprowadzenia kontroli przez sąd powszechny ${ }^{35}$.

Bardzo ważny w perspektywie bezpośredniego stosowania Konstytucji jest przepis art. 77 Konstytucji. W wyroku SN z 2002 r. ${ }^{36}$ wskazano, że przepis ten może stanowić podstawę roszczenia o naprawienie szkody wyrządzonej przez wydanie w postępowaniu podatkowym decyzji niezgodnej z prawem, następnie uchylonej w wyniku odwołania wniesionego przez podatnika ${ }^{37}$. Natomiast w wyroku SN z 2006 r. ${ }^{38}$ opowiedziano się za współstosowaniem i aakcentowano, że art. 417 k.c. ${ }^{39} \mathrm{w}$ zw. z art. 77 ust. 1 Konstytucji może stanowić podstawę odpowiedzialności Skarbu Państwa za szkodę wyrządzoną w powyższych okolicznościach ${ }^{40}$. Także w kontekście art. 77 ust. 1 Konstytucji orzecznictwo uznało uiszczone odsetki za zwłokę od zaległości podatkowej ustalonej ostateczną decyzją wydaną w toku kontrolnego postępowania podatkowego za mieszczące się w pojęciu szkody podlegającej naprawieniu na podstawie art. 417 $\S 1$ k.c. ${ }^{41} \mathrm{O}$ ile istnieje w orzecznictwie kontrowersja, czy art. 77 ust. 1 Konstytucji stanowić może podstawę samodzielną, który to pogląd w szczególnych

spełniają wymogów proporcjonalności ze względu na skalę represyjności wysokości wymierzanej kary. Naruszenie zasady proporcjonalności dostrzeżone zostało przez TK w odniesieniu do kar pieniężnych z ustawy o odpadach w wyroku z 15 października 2013 r. P 26/11, (Dz. U. 2013, poz. 1426). W orzeczeniu tym TK wskazał, że art. 79c ust. 3 nieobowiąujaceej ustawy z 27 kwietnia 2001 r. o odpadach w brzmieniu obowiązujacym od 12 marca 2010 r. do 19 lipca 2011 r., przez to, że przewidywał niepodlegającą miarkowaniu karę pieniężną w wysokości 10000 zł za nieterminowe przekazanie zbiorczego zestawienia danych o odpadach, był niezgodny z art. 2 Konstytucji RP z uwagi na naruszenie zasady proporcjonalności.

${ }_{35}$ Wyr. SN z 17 września 2014 r., I CSK 439/13, Legalis.

36 Wyr. SN z 6 lutego 2002 r., V CKN 1248/00, Legalis.

${ }^{37}$ Możliwość traktowania art. 77 ust. 1 Konstytucji jako samoistnej podstawy roszczeń odszkodowawczych uznano również w wyr. SN: z 8 stycznia 2002 r., I CKN 581/99, OSP 2002, nr 11, poz. 143, z glosa M. Kępińskiego; z 6 lutego 2002 r., V CKN 1248/00, OSP 2002, nr 10, poz. 128, z glosą R. Mastalskiego; z 24 września 2003 r., I CKN 143/03, OSNC 2004, nr 6, poz. 78; uchw. SN(7) z 19 maja 2009 r., III CZP 139/08, OSNC 2009, nr 11, poz. 144; uchw. SN(7) z 26 kwietnia 2006 r., III CZP 125/05, OSNC 2006, nr 12, poz. 194.

38 Wyr. SN z 17 marca 2006 r., I CSK 64/05, Legalis.

${ }^{39} \mathrm{~W}$ brzmieniu obowiązującym przed wejściem w życie ustawy z 17 czerwca 2004 r. o zmianie ustawy Kodeks cywilny oraz niektórych innych ustaw, Dz. U. Nr 162, poz. 1692.

${ }^{40}$ Podobnie: wyr. SN z 12 lutego 2010 r., I CSK 328/09, Legalis; wyr. SN z 20 lutego 2008 r., II CSK 435/07, Legalis; wyr. SN z 18 grudnia 2003 r., I CK 443/02, Legalis. Uznający naruszenie art. 77 ust. 1 Konstytucji RP i art. 417 k.c. Tak też: wyr. SN z 19 listopada 2004 r., V CK 250/04, Legalis; post. SN z 30 maja 2003 r. III CZP 34/03, Legalis; wyr. SN z 9 lipca 2003 r., IV CKN 357/01, Legalis.

41 Wyr. SN z 18 listopada 2005 r., IV CK 190/05, Legalis. 
sytuacjach braku współpodstawy normatywnej wydaje się bardziej przekonujący, to jednak ponad wszelką wątpliwość podlega on wpółstosowaniu ${ }^{42}$. We wskazanym na wstępie judykacie SN słusznie opowiedział się za bezpośrednim stosowaniem samodzielnym art. $77 \S 1 \mathrm{w}$ zw. z art. 8 ust. 2 Konstytucji, jeżeli szkoda istnieje i ma związek z decyzjami organu władzy publicznej ${ }^{43}$. W orzecznictwie przyjmuje się zarazem, że odpowiedzialność Skarbu Państwa za szkodę wyrządzona przez niezgodne $\mathrm{z}$ prawem działanie lub zaniechanie przy wykonywaniu władzy publicznej należy rozumieć jako naruszenie nakazu czy zakazu wynikającego tylko z normy prawnej, a nie zasad współżycia społecznego $^{44}$. Bliższą analizę problematyki bezpośredniego stosowania art. 77 Konstytucji przedstawiono w innym opracowaniu ${ }^{45}$.

\section{STOSOWANIE KONSTYTUCJI WPROST. REGULY KOLIZYJNE}

\section{Samoistne stosowanie Konstytucji}

Stosunkowo rzadko bywa, by norma konstytucyjna miała wystarczająco konkretną i precyzyjną treść, by mogła stanowić samoistną podstawę rozstrzygnięcia. Niektóre jednak przepisy Konstytucji mogą być stosowane wprost przez sądy powszechne lub administracyjne. W wyroku SN z 2009 r. ${ }^{46}$ wskazano, że norma konstytucyjna może stanowić podstawę prawną jeżeli jest skonkretyzowana w stopniu pozwalajaccym na samoistne jej zastosowanie ${ }^{47}$; Sąd podkreślił, że wyrażona w art. 8 ust. 2 Konstytucji zasada bezpośredniego stosowania Konstytucji oznacza stosowanie jej norm przez organy władzy publicznej bez konieczności pośrednictwa ustawy, choć jednak normy konstytucyjne o takim stopniu konkretyzacji nie są liczne ${ }^{48}$.

Bezpośrednie samoistne stosowanie Konstytucji, opierające się na przedstawionym mechanizmie widoczne jest na tle problemu odpowiedzialności senatora za słowo. Sąd Najwyższy, opierając swe rozstrzygnięcie na normie konstytucyjnej, wskazał, że art. 105 ust. 1 zd. 2 Konstytucji wprowadził immunitet formalny chroniący parlamentarzystę przed odpowiedzialnościa sa dową (w tym cywilna) za naruszenie praw osób trzecich; do pociagnięcia posła

${ }^{42}$ Por. wyr. SN z 19 stycznia 2005 r., IV CK 262/04, Legalis; wyr. SN z 9 lipca 2003 r., IV CKN 357/01, Legalis; wyr. SN z 21 listopada 2001 r., V CK 50/03, Legalis.

43 Odmienne stanowisko wyrażono np. w wyr. SN z 23 marca 2004 r., V CK 376/03, niepubl.; wyr. SN z 23 kwietnia 2004 r., I CK 591/03, Legalis.

${ }^{44}$ Wyr. SN z 7 listopada 2013 r., V CSK 519/12, Legalis.

45 Por. M. Gutowski, P. Kardas, op. cit., s. 667-674.

${ }^{46}$ Wyr. SN z 8 stycznia 2009 r., I CSK 482/08, Legalis.

47 Tak również: np. wyrok SN z 9 maja 2003 r., V CK 344/02, OSNC 2004, nr 7-8, poz. 119, oraz wyrok TK z 23 września 2003 r., K 20/02, OTKA 2003, nr 7, poz. 76.

48 Przykładowo, jak wskazano w wyr. SN z 2 grudnia 2011 r., III CSK 76/11, Legalis, art. 2,7 i 83 Konstytucji nie mogą stanowić podstawy prawnej rozstrzygnięcia w niniejszej sprawie. Przepisy te są źródłem gwarancji praw obywatelskich, realizowanych poprzez przepisy ustaw, stanowią więc wzorzec konstytucyjny służący do oceny konstytucyjności ustaw, a nie źródło uprawnień dochodzonych na drodze sądowej. 
(senatora) do odpowiedzialności z tego tytułu potrzebna jest bowiem zgoda właściwej izby parlamentu. Od wejścia w życie Konstytucji na podstawie bezpośredniego zastosowania tego przepisu (art. 8 ust. 2 Konstytucji) posłowie i senatorowie objęci zostali wspomnianym immunitetem. Jak podkreśla SN, zasada bezpośredniego stosowania Konstytucji oznacza, że na podstawie bezpośrednio zastosowanego art. 105 Konstytucji każdy organ władzy publicznej, w tym sąd, ma obowiązek uwzględnić wynikającą z niego ochronę wobec osób, które ją uzyskały od daty wejścia w życie Konstytucji z 1997 r. ${ }^{49}$ W tym przypadku norma konstytucyjna stanowiła samoistną i wystarczająca podstawę rozstrzygnięcia sądowego w sprawie indywidualnej.

Najbardziej aktualnym przykładem zastosowania bezpośredniego normy konstytucyjnej jako samodzielnej podstawy rozstrzygnięcia jest uchwała SN z 2017 r. ${ }^{50}$, podejmowana $\mathrm{w}$ toku oceny kasacyjnej zasadności umorzenia postępowania w kontekście podniesionego zarzutu przedwczesności prezydenckiego prawa łaski. W uchwale tej stwierdzono: „Prawo łaski, jako uprawnienie Prezydenta RP określone w art. 139 zdanie pierwsze Konstytucji RP, może być realizowane wyłącznie wobec osób, których winę stwierdzono prawomocnym wyrokiem sądu (osób skazanych). Tylko przy takim ujęciu zakresu tego prawa nie dochodzi do naruszenia zasad wyrażonych w treści art. $10 \mathrm{w}$ zw. z art. 7, art. 42 ust. 3, art. 45 ust. 1, art. 175 ust. 1 i art. 177 Konstytucji RP. Zastosowanie prawa łaski przed datą prawomocności wyroku nie wywołuje skutków procesowych". W tym przypadku prezydent, korzystając z prawa łaski, wskazał, że wykonuje swe uprawnienia konstytucyjne, a zatem w tym konkretnym przypadku SN dokonał oceny zakresu prezydenckiego uprawnienia bezpośrednio w ramach samej normy konstytucyjnej.

\section{Reguła lex superior i mechanizm kolizyjny w orzecznictwie sądowym}

Wśród reguł kolizyjnych najbardziej kontrowersyjna, a zarazem najpowszechniej rozpoznawana formułą dokonywania bezpośredniego stosowania Konstytucji jest odmowa zastosowania sprzecznego z Konstytucja przepisu ustawy zgodnie z reguła lex superior derogat legi inferiori. Przykładem orzeczenia, w którym taką możliwość dopuszczono, jest wyrok NSA z 2008 r. ${ }^{51}$

Stosowanie przez sądy reguły walidacyjnej lex superior jest powszechnie akceptowane w odniesieniu do podustawowych aktów normatywnych i stanowi zarazem wyraz akceptacji kompetencji sądów co do ostatecznej decyzji o stosowaniu prawa ${ }^{52}$ zgodnie $\mathrm{z}$ akcentowanym $\mathrm{w}$ orzecznictwie założeniem,

${ }^{49}$ Wyr. SN z 24 października 2001 r., III CKN 268/99, Legalis.

${ }^{50}$ Uchw. SN (7) z 31 maja 2017 r., I KZP 4/17, niepubl.

${ }^{51}$ Wyr. NSA z 24 września 2008 r., I OSK 1369/07, Legalis.

${ }^{52}$ Wyr. SN z 25 sierpnia 2011 r., II CNP 11/11, Legalis; wyr. SN z 23 kwietnia 2009 r., IV CNP 99/08, Legalis; wyr. SN z 23 kwietnia 2009 r., IV CNP 99/08, Legalis; wyr. SN z 3 grudnia 2008 r., V CSK 310/08, Legalis; wyr. SN z 26 września 2007 r., III KK 206/07, niepubl.; wyr. SN z 6 grudnia 2006 r., IV CSK 247/06, Legalis; wyr. SN z 4 lipca 2001 r., ZP 12/01, OSNAP 2002, nr 3, poz. 34; wyr. NSA z 22 lutego 2006 r., I FSK 1074/05, ONSAiWSA 2006, nr 5, poz. 136; wyr. NSA z 16 stycznia 2006 r., I OPS 4/05, ONSAiWSA 2006, nr 2, poz. 3; wyr. WSA Gliwicach z 7 sierpnia 
że „uznanie przez sąd powszechny za sprzeczny z Konstytucją lub przepisami rangi ustawowej przepisów rozporządzenia (aktu podustawowego), uprawnia do odmowy jego zastosowania w rozstrzyganej sprawie”. Uznaje się, że sądy uprawnione są do odmowy zastosowania rozporządzenia z uwagi na jego sprzeczność z ustawą zasadniczą ${ }^{53}$.

Mechanizm powyższy jest klasycznym schematem mechanizmu uzasadniającego odmowę stosowania niezgodnego z Konstytucją przepisu ustawowego. Tyle że kolizja przepisów zachodzi w tym ostatnim przypadku na hierarchicznie wyższym poziomie.

Reguła walidacyjna lex superior ma niebagatelne znaczenie w sprawach, w których pojawiają się wątpliwości na tle temporalnych konsekwencji orzeczeń TK. Jednym z takich orzeczeń jest wyrok SA w Poznaniu z 2015 r. ${ }^{54}$, w którym wskazano, że zasadą jest, że przepisy art. 190 Konstytucji nie określają czasowych skutków orzeczeń TK. W orzecznictwie SN przyjmuje się, że orzeczenia stwierdzające niezgodność w szczególności przepisów ustaw z Konstytucją co do zasady sa skuteczne ex tunc. Stanowisko to najpełniej zostało przedstawione w uchwale SN z 2014 r. ${ }^{55}$

Należy przyjąć, że gdyby - pomimo braku utraty mocy obowiązującej przepisu w okresie „trybunalskiej” vacatio legis w tym czasie - zastosowanie zakwestionowanego przez TK przepisu miało prowadzić do niesprawiedliwego rozstrzygnięcia w jednostkowej sprawie, sąd powinien odmówić zastosowania tego przepisu, mimo że formalnie nie utracił on mocy obowiąujaccej ${ }^{56}$. Jak trafnie orzekł SN w 2016 r., stanowisko zajęte przez TK w nieopublikowanym w Dzienniku Ustaw wyroku, mimo jego nieogłoszenia i niewprowadzenia do sfery normatywnej, jest wiążące w sferze jurysdykcyjnej ${ }^{57}$. Sąd wskazał też

2014 r., II SA/Gl 352/14, Legalis; wyr. SN z 22 listopada 2000 r., II CKN 897/98, Legalis; wyr. SO w Częstochowie z 27 lipca 2012 r., IV U 1820/11, niepubl.; wyr. SO w Częstochowie z 6 lipca 2012 r., IV U 1746/11, niepubl.; wyr. SO w Częstochowie z 14 grudnia 2012 r., IV U 1833/11, niepubl.

${ }^{53}$ Wyr. SN z 25 sierpnia 2011 r., II CNP 11/11, Legalis; wyrok SN z 23 kwietnia 2009 r., IV CNP 99/08, Legalis.

${ }^{54}$ Wyr. SA w Poznaniu z 4 listopada 2015 r., I ACa 543/15.

${ }^{55}$ Uchw. SN z 15 maja 2014 r., II CSK 444/13. Lex nr 1496279. Por też: uchwała SN z 3 lipca 2003 r., III CZP 45/03, OSNC 2004, nr 9, poz. 136; wyrok SN z 9 października 2003 r., I CK 150/02, OSNC 2004, nr 7-8, poz. 132; wyr. z 29 października 2003 r., III CK 34/02, OSP 2005, nr 4, poz. 54; uchwała SN z 23 stycznia 2004 r., III CZP 112/03, OSNC 2005, nr 4, poz. 61; post. SN z 15 kwietnia 2004 r., IV CK 272/03, niepubl.; wyr. SN z 30 września 2004 r., IV CK 20/04, OSNC 2005, nr 9, poz. 161; wyr. SN z 26 listopada 2004 r., V CK 270/04, niepubl.; uchw. SN z 23 czerwca 2005 r., III CZP 35/05, OSNC 2006, nr 5, poz. 81; wyr. SN z 7 października 2005 r., II CK 756/04, „Monitor Prawniczy” 2005, nr 21, s. 1027; uchw. SN z 19 maja 2006 r., III CZP 26/06, OSNC 2007, nr 3, poz. 39; wyr. SN z 14 września 2006 r., III CSK 102/06, niepubl.; uchw. SN (7) z 7 grudnia 2006 r., III CZP 99/06, OSNC 2007, nr 6, poz. 79; wyr. SN z 15 czerwca 2007 r., II CNP 37/07, niepubl.; wyr. SN z 13 grudnia 2007 r., I CSK 315/07, niepubl., wyr. SN z 19 czerwca 2008 r., V CSK 31/08, OSNC-ZD 2009, nr 1, poz. 16; wyr. SN z 20 maja 2009 r., I CSK 379/08, niepubl.

${ }^{56}$ Co więcej, wyrok TK odraczający w czasie utratę mocy obowiązującej zakwestionowanego przepisu uniemożliwia wznowienie postępowania zakończonego przed upływem terminu określonego w sentencji takiego wyroku, skoro bowiem zakwestionowany przepis nadal jest stosowany, nietrafne jest twierdzenie, że wydawane na jego podstawie orzeczenia mogłyby być następnie kwestionowane w drodze wznowienia postępowania. Tak: wyr. SN z 20 kwietnia 2011 r., I CSK 410/10, OSNC 2012, nr 1, poz. 14, s. 88.

${ }^{57}$ Post. SN z 24 listopada 2016 r., V CZ 86/16, niepubl. 
w omawianym judykacie, że zważywszy, iż TK zdecydował się na odroczenie utraty mocy obowiązującej kontrolowanego przepisu na okres 18 miesięcy, W związku z czym pozostaje on elementem stanu prawnego, na SN oraz na sądach pozostał ciężar takiej wykładni, która minimalizuje jego niekonstytucyjność albo - jeżeli to w konkretnej sprawie możliwe - w ogóle ją znosi. Podążając podobnym tokiem rozumowania, słusznie wskazano w oddalającym powództwo wyroku SR w Częstochowie z 2015 r. ${ }^{58}$ o zasądzenie opłaty za dozór techniczny urządzenia na podstawie zakwestionowanego przez TK przepisu w okresie trybunalskiej vacatio legis, odroczenie terminu w myśl art. 190 $\S 3$ Konstytucji nie oznacza bowiem automatycznego przyjęcia fikcji, że zakwestionowane przepisy w okresie odroczenia nie sa sprzeczne z porządkiem konstytucyjnym. Przeciwnie, orzecznictwo jednoznacznie potwierdza, że nie jest tak, iż przepis prawa danego dnia jest zgodny, a po upływie tego dnia jest niezgodny z Konstytucją od samego początku, bez względu na to, czy TK skorzystał, czy nie skorzystał z uprawnienia odroczenia skutku braku wiązania z art. $190 \S 3$ Konstytucji ${ }^{59}$. Jeżeli zatem odroczenie skutku braku wiązania nie eliminuje jego sprzeczności z porządkiem prawnym od samego początku, to uzasadnione jest pytanie o cel instytucji odroczenia. Orzecznictwo w tym zakresie wyjaśnia, że „samo odroczenie ma na celu umożliwienie odpowiedniemu organowi stosowną zmianę przepisu, tak aby stał się zgodny z Konstytucją lub innym nadrzędnym aktem prawa" ${ }^{00}$. Z tego wynika, że cel odroczenia nakierowany przede wszystkim jest na funkcjonowanie państwa i jego organów, a nie na zakres praw obywatelskich i cywilnych jednostek. Nadrzędna zaś poszanowania praw obywatelskich i cywilnych - i tym samym - naczelną wartością konstytucyjna, jest zasada rządów prawa oznaczająca w największym skrócie to, że to co jest sprzeczne $\mathrm{z}$ prawem, nie może wiązać obywatela w sferze jego uprawnień. Na tej zasadzie opiera się w końcu mechanizm zaufania obywatela do państwa i jego organów. W podobnej sytuacji sądy konsekwentnie zasądzają od powiatów niezasadnie pobraną na podstawie niekonstytucyjnych przepisów kartę pojazdu, pomimo formalnego ich obowiązywania, zwykle powołując się zarazem na niezgodność kwestionowanych przepisów z prawem unijnym ${ }^{61}$.

Pogląd, że sądy powszechne i administracyjne nie tylko moga, lecz wręcz muszą samodzielnie rozstrzygać sprawy za pomocą bezpośredniego stosowania Konstytucji, wykorzystując wszystkie reguły wykładnicze, w tym wyjątkowo również regułę lex superior derogat legi inferiori, znajduje szerokie i uzasadnione odbicie w orzecznictwie sądowym. Pogląd ten najdobitniej został wyrażony w wyroku SA w Poznaniu z 2003 r. ${ }^{62} \mathrm{Z}$ uwagi na doniosłość argumentacji,

${ }^{58}$ Wyr. SR w Częstochowie z 26 czerwca 2015 r., I C 603/15, niepubl.

${ }^{59}$ Por. też: wyr. NSA z 17 czerwca 2011 r., I OSK 1892/10; wyr. WSA w Poznaniu z 25 czerwca 2014 r., II SA/Po 327/14.

${ }^{60}$ Wyrok NSA z 17 czerwca 2011 r., I OSK 1892/10.

${ }^{61}$ Wyr. SR w Nakle n. Notecią z 3 marca 2015 r., I C 362/15; wyr. SR w Gdyni z 4 października 2012 r., I C 956/12; wyr. SR w Starogardzie Gdańskim z 30 października 2014 r., I C 1188/14. Por. też post. TSUE z 10 grudnia 2007 r., C-134/07, Piotr Kawala przeciwko gminie miasta Jaworzna, EU:C:2007:770.

${ }^{62}$ Wyr. SA w Poznaniu z 15 kwietnia 2003 r., I ACa 178/03. 
pogląd ten wart jest przytoczenia w całości: „Podzielając pogląd, że nie jest rzeczą sądu powszechnego orzekać o utracie mocy przepisów ustawowych należy zwrócić uwagę na różnicę między derogacją przepisów ustawowych dokonywana przez Trybunał Konstytucyjny a odmową zastosowania przez sąd powszechny przepisu ustawy sprzecznego z Konstytucja. Trzeba także zauważyć, że pogląd o obowiązku zwracania się w tym przypadku z pytaniem prawnym do Trybunału Konstytucyjnego jest sprzeczny z jednoznaczną treścią art. 193 Konstytucji. Stanowi on, bowiem, że "sąd może» przedstawić Trybunałowi pytanie prawne. Gdyby ustrojodawca zamierzał wyłączyć możliwość odmowy stosowania przez sąd ustawy sprzecznej z Konstytucja, to powinien w odniesieniu do niezgodności tych dwóch źródeł prawa użyć zwrotu "sąd przedstawia" pytanie prawne. Z przepisów stanowiących, iż Konstytucja jest najwyższym prawem stosowanym bezpośrednio (chyba, że stanowi ono inaczej), podległości sędziów tylko Konstytucji i ustawom (art. 178 ust. 1 Konstytucji) oraz z braku obowiązku sądu zwracania się do Trybunału z pytaniem prawnym wynika, iż sąd może - stosując zasadę lex superior derogat legi inferiori - odmówić stosowania ustawy sprzecznej z Konstytucja. Zdaniem Sądu Apelacyjnego rzeczywiście w przypadku, gdy istnieją wątpliwości, co do zgodności przepisu ustawy z Konstytucją sąd powszechny winien wystapić z takim zapytaniem. Sama bowiem instytucja zapytania prawnego - mimo, że w Konstytucji tego nie wyartykułowano wprost - zakłada istnienie wątpliwości gdyż pyta ten, który nie wie. Odmienna jednak sytuacja zachodzi, gdy przepis ustawy majacy znaczenie dla rozstrzygnięcie sprawy jest w sposób oczywisty niekonstytucyjny. Gdy sąd dojdzie do przekonania, że przepis ustawy Konstytucję narusza, a stwierdzenie to rysuje się mu jako oczywiste powinien wówczas odstapić od zastosowania niekonstytucyjnego przepisu. Nie może on, bowiem stosować ustawy sprzecznej z Konstytucja. Wybór postępowania należy do sądu, a jego prawidłowość - w przypadku odmowy stosowania ustawy - podlega kontroli instancyjnej. Takie rozstrzygnięcie sądu ma oczywiście zupełnie inny walor niż orzeczenie Trybunału Konstytucyjnego stwierdzające niezgodność danego przepisu z Konstytucja, bowiem uczynione jest jedynie na użytek rozpoznawanej właśnie sprawy. Odmowa zastosowania ustawy przez sąd nie narusza też konstytucyjnych kompetencji Trybunału Konstytucyjnego (art. 188 pkt 1) do pozbawienia jej mocy. Przedmiotem orzekania sądu jest, bowiem indywidualny stosunek społeczny, a Trybunał orzeka o prawie. Wykonując władzę sądowniczą (art. 10 ust. 2 Konstytucji) sąd sprawuje wymiar sprawiedliwości (art. 175 ust. 1 Konstytucji), zaś Trybunał, orzekając o zgodności ustaw z Konstytucja, wykonuje bardziej władzę ustawodawcza - ustawodawcy negatywnego - niż sądownicza, (mimo że art. 10 ust. 2 Konstytucji zalicza go do władzy sądowniczej). Fakt, iż przepis art. 20 ustawy z dnia 16 grudnia 1972 r. o świadczeniach przysługujaccych w razie wypadków i chorób pozostających w związku ze służbą wojskową (Dz. U. Nr 53, poz. 342 ze zm.), ograniczajacy - a w określonych sytuacjach wyłączajacy - możliwość dochodzenia przez poszkodowanego żołnierza, na zasadach prawa cywilnego, odszkodowanie lub zadośćuczynienie za szkodę z tytułu wypadku lub choroby pozostających w związku ze służbą wojskowa, jest sprzeczny z Konstytucja jest nie tylko oczywisty, ale był już także wyrażony w wyroku Sądu Najwyższego z dnia 26 września 2000 r. 
III CKN 1089/00 (OSNC 2001/3/37). Pozostaje on w szczególności w sprzeczności z art. 2, 32 i 77 Konstytucji Rzeczpospolitej Polskiej. Należy, bowiem wskazać, że art. 2 proklamuje, iż Rzeczpospolita Polska jest demokratycznym państwem prawnym, urzeczywistniającym zasady sprawiedliwości społecznej, art. 32 ust. 1 zdanie pierwsze Konstytucji zapewnia wszystkim równość wobec prawa, a art. 77 ust. 2 zakazuje zamykać obywatelom drogę sądową dochodzenia naruszonych wolności lub praw. Z kolei art. 77 ust. 1 gwarantuje każdemu prawo do wynagrodzenia szkody, jaka została wyrządzona przez niezgodne z prawem działanie organu władzy publicznej".

Opierając się na mechanizmie rozumowania zasadzajacym się na regule walidacyjnej lex superior, SN samodzielnie rozstrzygnął, że przepis ograniczający - a w określonych sytuacjach wyłączający - możliwość dochodzenia przez poszkodowanego żołnierza, na zasadach prawa cywilnego, odszkodowania lub zadośćuczynienia za szkodę z tytułu wypadku lub choroby pozostających w związku ze służba wojskową jest sprzeczny z Konstytucja, i tym samym otworzył drogę do realizacji roszczeń odszkodowawczych ${ }^{63}$. Ten sam mechanizm kolizyjny zastosowany został przez SA w Katowicach jako podstawa odmowy zastosowania art. 32 § 1a Pr. Spółdz. z uwagi na jego niezgodność z Konstytucją RP, a konsekwencji doprowadził do zastosowania jako podstawy prawnej rozstrzygnięcia bezpośrednio i wyłącznie przepisów art. 2, 32 i 77 Konstytucji. Istotny niedosyt wywołuje natomiast fakt, że orzeczenie to zakwestionował SN, niesłusznie uznając, że w tym zakresie kompetencje sądu są wyłączone ${ }^{64}$. Kluczowe w tej sprawie było, że SA w Katowicach wypowiedział pogląd o odmowie stosowania przepisu ustawowego na tle konkretnego stanu faktycznego, który wskazywał na to, że powódka ze względu na stan zdrowia i wiek nie miała rozeznania co do znaczenia podejmowanych wobec niej przez spółdzielnię środków prawnych, a zatem że zastosowanie niekonstytucyjnego przepisu musiałoby doprowadzić do wydania orzeczenia niesłusznego. Rację miał też SA, wskazując, że odmowa zastosowania przepisu w sprawie ma takie znaczenie, że sąd, stwierdziwszy „niekonstytucyjność" danego przepisu, uwzględnia ten fakt przy orzekaniu o indywidualnym stosunku w rozpoznawanej sprawie, a jego pogląd nie jest wiążący dla innych sądów orzekających $\mathrm{w}$ analogicznych sprawach. To uprawnienie sądu nie uchybia kompetencji TK, którego orzeczenie jest powszechnie obowiązujące i ostateczne (art. 188 pkt 1 Konstytucji).

Bardzo ciekawym przykładem zastosowania reguły lex superior derogat legi inferiori jest sytuacja, w której sąd ma zastosować przepis art. $70 \S 8$ OP, którego identyczny treściowo odpowiednik został uprzednio uznany za niezgodny z Konstytucja ${ }^{65}$. W takiej sytuacji faktycznej samodzielnego rozstrzygnięcia na podstawie przepisów Konstytucji dokonał SN w 2016 r. ${ }^{66}$, odmawiajac zastosowania wspomnianego art. $70 \S 8$ OrdPU z uwagi na stwierdzenie jego niezgodności z ustawą zasadniczą. W uzasadnieniu tego

\footnotetext{
${ }^{63}$ Wyrok SN z 26 września 2000 r., III CKN 1089/00, OSNC 2001, nr 3, poz. 37.

${ }^{64}$ Wyr. SN z 25 lipca 2003 r., V CK 47/02, Legalis.

${ }^{65}$ Wyr. TK z 8 października 2013 r., SK 40/12, Dz. U. 2013, poz. 1313.

${ }^{66}$ Wyr. SN z 17 marca 2016 r., V CSK 377/15, OSNC 2016, nr 12, poz. 148.
} 
judykatu SN trafnie wskazał, że jeżeli niezgodność przepisu z Konstytucją jest $\mathrm{w}$ związku z rozpoznawana sprawa oczywista i ocena taka ma dodatkowe poparcie w wyroku TK, który stwierdził uprzednio niezgodność z Konstytucją przepisu o takim samym brzmieniu, jak zawarty w obowiązujacej ustawie, to sąd może nie zastosować tego przepisu w rozpoznawanej sprawie ze względu na jego niezgodność z Konstytucją. SN wskazał zarazem, że do orzekania o niezgodności ustaw i ich poszczególnych przepisów z Konstytucją jest powołany wyłącznie TK (art. 188 pkt 1 oraz art. 193 Konstytucji). Wyrok powyższy został $\mathrm{w}$ orzecznictwie trafnie odczytany jako potwierdzenie prawa sądu powszechnego do bezpośredniego stosowania Konstytucji z zastosowaniem reguł walidacyjnych, które może być dokonywane jedynie na tle konkretnego stanu faktycznego oraz w indywidualnej sprawie. Taka „kontrola konstytucyjności” koncentruje się wyraźnie na procesie wykładni i stosowania prawa, a nie na analizie abstrakcyjnej - trybunalskiej. Podobna zasada obowiąuje w doktrynie acte eclaire, która w prawie Unii Europejskiej oznacza, że jeżeli TSUE wydał już wcześniej orzeczenie w sprawie wykładni danego przepisu prawa wspólnotowego, to ma ono zastosowanie również w późniejszych przypadkach i podnoszenie pytania prejudycjalnego w zakresie danego przepisu nie jest obowiązkowe, a poprzednie orzeczenie TSUE w tej sprawie wiążące ${ }^{67}$. Analogiczny problem podobnie rozstrzygną SA w Gdańsku ${ }^{68}$, uznając za nieuzgadnialną z Konstytucją wykładnię art. $70 \S 8$ OrdPU przyjmująca, że należności zabezpieczone hipoteką przymusowa nie ulegają przedawnieniu. Stwierdzając niekonstytucyjność art. 25 ustawy o systemie ubezpieczeń zdrowotnych, SA uchylił zaskarżony wyrok i przekazał sprawę do ponownego rozpoznania, nakazując zbadanie problematyki przedawnienia.

Zastosowanie reguły walidacyjnej lex superior derogat legi inferiori widoczne jest w wyroku SA we Wrocławiu z $2017 \mathrm{r.}^{69}$ odmawiającym uczynienia podstawą orzeczenia dowodów nielegalnych wskazującym zarazem, że „dowód może zostać uznany za niedopuszczalny, jeżeli został uzyskany z naruszeniem przepisów postępowania lub za pomocą czynu zabronionego przy jednoczesnym naruszeniu przepisów Konstytucji RP (np. art. 30, 47, 49 czy 51)". W realiach konkretnej sprawy SA doszedł do przekonania, że wykorzystanie dowodów przeciwko oskarżonym, zdobytych z naruszeniem przepisów postępowania, zdobytych za pomocą prowokacji osoby współpracującej, jest niezgodne z rzetelnym, sprawiedliwym procesem. Wykorzystanie tych dowodów narusza art. 6 ust. 1 EKPC, zgodnie zaś z art. 91 ust. 2 Konstytucji umowa międzynarodowa ratyfikowana za uprzednią zgodą wyrażoną w ustawie ma pierwszeństwo przed ustawa, jeżeli ustawy tej nie da się pogodzić z umowa. W tym przypadku jednak o uniewinnieniu zadecydowała reguła lex superior $\mathrm{w}$ relacji z umową międzynarodową oraz prokonstytucyjna wykładnia.

\footnotetext{
67 Wyr. SR w Gdyni z 28 lutego 2017 r., IV P 165/16.

68 Wyr. SA w Gdańsku z 30 marca 2017 r., III AUa 1644/16.

69 Wyr. SA we Wrocławiu z 27 kwietnia 2017 r., II AKa 213/16, niepubl.
} 
Podobny mechanizm widoczny jest w wyroku WSA w Poznaniu z 2017 r. ${ }^{70}$ oraz zdaniu odrębnym do wyroku WSA w Poznaniu z 2017 r. ${ }^{71}$, w którym zaakcentowano sprzeczność art. 12 ust. 1 pkt 2 ustawy z 5 stycznia 2011 r. o kierujących pojazdami ${ }^{72}$ - zakazującego wydanie prawa jazdy osobie, wobec której orzeczono zakaz prowadzenia pojazdów mechanicznych w konkretnej kategorii, także co do innych kategorii - z art. 2 Konstytucji, przez złamanie zasady ne bis in idem podwójnym karaniem tej samej osoby fizycznej za popełnienie tego samego czynu zabronionego ${ }^{73}$.

Interesujacego przykładu w tym zakresie dostarczaja orzeczenia SR w Koninie z 2016 r. $^{74}$ dotyczące roszczeń pracowniczych. W jednej ze spraw powództwo obejmowało żądanie waloryzacyjne wynagrodzenia pracowników sądów oraz prokuratur obejmujace lata 2011, 2012 i 2013, w których ustawodawca zaprzestał waloryzacji w ustawie budżetowej, co nastapiło - w ocenie sądu - wbrew konstytucyjnej zasadzie zaufania obywateli do państwa i stanowionego przez nie prawa (art. 2), ochrony warunków pracy (art. 24), zasadzie równości (art. 32) i zasadzie ochrony praw majątkowych. W tych warunkach SR zastosował miernik waloryzacji oparty o prognozowany średnioroczny wzrost cen i usług konsumpcyjnych na dany rok budżetowy, odmawiając jednocześnie zastosowania niezgodnego z Konstytucją przepisu ustawy i powołując się w tym zakresie na orzecznictwo sądowe, zwłaszcza sądów administracyjnych ${ }^{75}$ oraz na wyrok SN z 2003 r. ${ }^{76}$, zgodnie z którym „odmowa zastosowania przepisu w sprawie ma takie znaczenie, że sąd stwierdziwszy "niekonstytucyjność» danego przepisu uwzględnia ten fakt przy orzekaniu o indywidualnym stosunku w rozpoznawanej sprawie, a jego pogląd nie jest wiążący dla innych sądów orzekających $\mathrm{w}$ analogicznych sprawach. To uprawnienie sądu nie uchybia kompetencji TK, którego orzeczenie jest powszechnie obowiąujace i ostateczne (art. 188 pkt 1 Konstytucji)”. Warto zaznaczyć, że SR podkreślił, że nie mógł w toku postępowania wystapić z pytaniem prawnym do TK, ponieważ orzekał na podstawie ustawy, która już nie obowiązywała w chwili orzekania i dlatego zdecydował się na rozstrzygnięcie samodzielne. W innym orzeczeniu dotyczącym waloryzacji, uwzględniajaccym prokonstytucyjną wykładnię podobną do przedstawionego wyżej rozstrzygnięcia zgodnie z regułą walidacyjną, sąd odwołał się do stanowiska TK ${ }^{77}$ uznającego niezgodność z konstytucyjną zasadą ochrony praw majątkowych ówczesnego ustawowego wyłączenia waloryzacji kaucji mieszkaniowych i w aktualnym stanie prawnym dokonał waloryzacji ${ }^{78}$.

${ }^{70}$ Wyr. WSA w Poznaniu z 8 marca 2017 r., II SA/Po 1034/16, niepubl.

${ }^{71}$ Zdanie odrębne sędziego WSA J. Zielińskiego do wyr. WSA w Poznaniu z 21 lutego 2017 r., IV SA/Po 601/16, niepubl.

${ }^{72}$ T.jedn.: Dz. U. 2016, poz. 627.

${ }^{73}$ Powołując się na wyrok TK z 8 października 2002 r., K 36/00.

${ }^{74}$ Co do pracowników sądów: wyr. SR w Koninie z 16 lipca 2016 r., IV P 735/13; wyr. SR w Koninie z 20 września 2016 r., IV P 445/13; wyr. SR w Koninie z 22 października 2015 r., IV P 226/15; wyr. SR w Koninie z 23 lipca 2015 r., IV P 239/15. Co do pracowników prokuratur: wyr. SR w Koninie z 9 czerwca 2015 r., IV P 675/13.

${ }^{75}$ Por. wyr. WSA z 19 września 2007 r., VIII SA/Wa 405/07, Lex nr 469855; wyr. NSA w Poznaniu z 14 lutego 2002 r., I SA/Po 461/01, OSP 2003/2/17; wyr. NSA w Warszawie z 9 października 1998 r., II SA 1246/98.

${ }^{76}$ Wyr. SN z 25 lipca 2003 r., V CK 47/02, Lex nr 157312.

${ }_{77}$ Wyr. TK z 3 października 2000 r., K 33/99, OTK ZU 2000, nr 6, poz. 188.

${ }^{78}$ Wyr. SR Poznań-Grunwald i Jeżyce z 3 lutego 2015 r., VI U 1625/14. 


\section{Czynniki warunkujące decyzję o samodzielnym rozstrzygnięciu lub wystąpieniu z pytaniem prawnym w trybie art. 193 Konstytucji}

Wydaje się, że ocenie sądowej powinna każdorazowo podlegać - w perspektywie wynikającego z art. 45 ust. 1 Konstytucji prawa do sprawiedliwego i bezzwłocznego orzeczenia oraz pełnej kompetencji sądu do samodzielnego rozstrzygnięcia problemu konstytucyjności ustawy - celowość skorzystania z możliwości wystapienia w tym zakresie z pytaniem prawnym do TK. W toku dokonywania tej oceny należy wziąć pod uwagę następujące kryteria:

1) istnienie orzeczeń TK rozstrzygajacych identyczne lub podobne relacje zgodności rozwiązań ustawowych z Konstytucja:

2) istnienie orzeczeń SN i innych sądów, ETS lub TSUE rozstrzygających identyczne lub podobne relacje zgodności rozwiązań ustawowych z ratyfikowanymi umowami międzynarodowymi lub z prawem unijnym;

3) istnienie orzecznictwa sądów powszechnych i administracyjnych, zwłaszcza SN lub NSA dotyczących rozstrzygnięć w podobnych sprawach za pomoca mechanizmów bezpośredniego stosowania Konstytucji;

4) stopień oczywistości relacji sprzeczności przepisu ustawowego z przepisem konstytucyjnym;

5) wpływ sprzeczności przepisu ustawowego z regulacją konstytucyjną na aspekt sprawiedliwościowy indywidualnego rozstrzygnięcia;

6) realny czas potrzebny do uzyskania odpowiedzi na pytanie ze strony TK oraz przewidywaną przydatność tej opowiedzi w zestawieniu z możliwością samodzielnego rozstrzygnięcia problemu konstytucyjnego przez sąd orzekający.

Jeśli analiza sytuacji w konkretnej sprawie w perspektywie powyższych kryteriów doprowadzi sąd do konkluzji, że bardziej efektywne i słuszniejsze będzie samodzielne rozstrzygnięcie konstytucyjnej relacji potencjalnej sprzeczności ustawy z ustawą zasadnicza, sąd powinien dokonać rozstrzygnięcia samodzielnego, realizując prawo jednostki do sprawiedliwego i bezzwłocznego orzeczenia (art. 45 ust. 1 Konstytucji). Obywatelskie prawo do sądu przeważa bowiem nad postulatem zapewnienia spójności orzecznictwa przez TK.

\section{BEZPOŚREDNIE STOSOWANIE KONSTYTUCJI. KONKLUZJE}

W polskim systemie prawnym orzeczenie odnoszące się do zgodności normy ustawowej z Konstytucja, zwiazane z przełamaniem (wzruszeniem) domniemania konstytucyjności na podstawie reguł walidacyjnych, możliwe jest w dwóch sytuacjach obejmujących konieczność rozstrzygnięcia problemu konstytucyjnego:

1) w toku tzw. kontroli abstrakcyjnej dokonywanej przez TK, w chwili rozstrzygnięcia o niekonstytucyjności normy abstrakcyjnej i generalnej zawartej w przepisie ustawy (już od chwili ogłoszenia orzeczenia), 
2) w toku stosowania prawa w indywidualnej sprawie przez sąd powszechny lub administracyjny, który może odmówić zastosowania niezgodnej z Konstytucja normy indywidualnej i konkretnej wyinterpretowanej z przepisu ustawy i rozstrzygnąc sprawę, bezpośrednio stosując normę wyinterpretowaną z Konstytucji lub stosując alternatywna, możliwą do zastosowania normę ustawowa, gdyby sąd doszedł do przekonania, że (koniunkcyjnie): (a) stosując sprzeczną z Konstytucją ustawową normę indywidualną i konkretna, (b) będzie musiał wydać orzeczenie niesprawiedliwe i naruszające konstytucyjne gwarancje, (c) zarazem norma konstytucyjna jest precyzyjna w stopniu umożliwiajacym jej bezpośrednie zastosowanie jako samoistnej podstawy rozstrzygnięcia lub istnieje alternatywna, możliwa do zastosowania i zgodna z Konstytucją norma ustawowa, a jednocześnie, (d) sąd nie dysponuje w danym przypadku możliwością rozstrzygnięcia kolizji ani na podstawie reguły przewidzianej w art. 91 ust. 2 lub 3 Konstytucji, z uwagi na sprzeczność tej normy z ratyfikowaną umową międzynarodową lub z prawem unijnym, ani nie ma możliwości uzgodnienia normy ustawowej z Konstytucją zgodnie z wykładnią prokonstytucyjną lub mechanizmem współstosowania normy Konstytucji oraz prokonstytucyjnie wyłożonej normy ustawy.

Mechanizmy te spina, pozostajacca w wyłacznej sferze kompetencyjnej, decyzja sądu o przedstawieniu pytania prawnego do TK (w trybie art. 193 Konstytucji) lub o rozstrzygnięciu problemu konstytucyjnego samodzielnie. Decyzja ta powinna być podejmowana zgodnie z kryteriami przedstawionymi powyżej, niemniej należy pamiętać, że Trybunał Konstytucyjny wypowiada się o zgodności z Konstytucją normy ustawowej w rozumieniu generalnym i abstrakcyjnym, sąd zaś o zgodności z Konstytucją normy ustawowej w rozumieniu indywidualnym i konkretnym, aplikowanym do konkretnego stanu faktycznego. Próba postawienia znaku równości pomiędzy tymi - komplementarnymi względem siebie - mechanizmami kontroli konstytucyjności opiera się zatem na błędzie przesunięcia kategorialnego. Mechanizmy te działaja bowiem na różnych poziomach, eliminacja zaś któregokolwiek z nich nie mogłaby pozostać bez szkody dla ochrony konstytucyjnych praw obywateli.

prof. dr hab. Maciej Gutowski

Uniwersytet im. Adama Mickiewicza w Poznaniu

DIRECT APPLICATION OF THE CONSTITUTION IN JUDICIAL PRACTICE

Sum mary

This article tackles direct application of the provisions of the Constitution. It examines in detail allegations of the violation of constitutional norms, the question of pro-constitutional interpretation of legal regulations, the application of the provisions of the Constitution in conjunction with the lower rank laws and interpretation in the compliance with the Constitution. It also presents the problem of a possible refusal to apply the provisions on the basis of validation rules. This article is based on the concept presented in a monograph written in cooperation with Professor dr. hab. Piotr Kardas (M. Gutowski, P. Kardas, Interpretation and Application of Law in a Constitution-based Process, Warsaw, 2017). A special attention has been given to some decisions of common courts, extensively discussed in Chapter 7 of this monograph. 
